\title{
Effect of Organic and Inorganic Sources of NPK and Bio-fertilizer on Enhancement of Growth Attributes and Chlorophyll Content of Sweet Potato
}

\author{
Jai Singh", M.K. Sharma, S.P. Singh, Rukshana Bano and A.K. Mahawar \\ Department of Horticulture, S.K.N. College of Agriculture, Jobner - 303 329, Jaipur, \\ Rajasthan, India \\ *Corresponding author
}

\section{A B S T R A C T}

\begin{tabular}{|l|}
\hline K e y w o r d s \\
$\begin{array}{l}\text { Ipomoea batatas, } \\
\text { Organic/ inorganic } \\
\text { sources, Bio- } \\
\text { fertilizers, Growth } \\
\text { attributes and } \\
\text { chlorophyll }\end{array}$ \\
\hline Article Info \\
\hline $\begin{array}{l}\text { Accepted: } \\
\text { 26 July 2018 } \\
\text { Available Online: } \\
\text { 10 September 2018 }\end{array}$ \\
\hline \hline
\end{tabular}

Keywords

Ipomoea batatas, Organic/ inorganic sources, Biofertilizers, Growth (l) and

Article Info

Accepted:

26 July 2018

10 September 2018

\begin{abstract}
A field experiment was conducted to study "Effect of organic and inorganic sources of NPK and bio-fertilizer on enhancement of growth attributes and chlorophyll content of sweet potato (Ipomoea batatas Lam.)" during Kharif season 2016 at Horticulture Farm, S.K.N. College of Agriculture, Jobner (Jaipur). The experiment consists of 16 treatment combinations viz., organic and inorganic sources of NPK (Control, $100 \%$ RDF, $100 \%$ $\mathrm{FYM}, 50 \% \mathrm{RDF}+50 \% \mathrm{FYM}, 100 \%$ vermicompost, $50 \% \mathrm{RDF}+50 \%$ vermicompost, $100 \%$ poultry manure and $50 \% \mathrm{RDF}+50 \%$ poultry manure) and bio-fertilizer (Control and Azotobacter) were tested in randomized block design with three replications. Result shows that application of $50 \% \mathrm{RDF}+50 \%$ vermicompost significantly increased the vine length at 45 DAP $(\mathrm{cm})$, number of branches per vine at 45 DAP, chlorophyll content in leaves $(\mathrm{mg} / \mathrm{g})$ at 50 DAP, leaf area $\left(\mathrm{cm}^{2}\right)$ at 45 DAP and leaf area index as compared to Control, $100 \%$ RDF, $100 \%$ FYM, 50\% RDF + 50 \% FYM, $100 \%$ vermicompost and 100 $\%$ poultry manure, which was statistically at par with $50 \%$ RDF $+50 \%$ poultry manure. The application of Azotobacter significantly increased all the growth parameters as compared to control.
\end{abstract}

\section{Introduction}

Sweet potato (Ipomoea batatas Lam., Family convolvulaceae) historically played an important role in the quest for food and the struggle for human survival in several countries. It is popularly known as "Sakar Kand" in India. It is a warm-season crop and grows best in abundant sunshine, temperatures above $24^{\circ} \mathrm{C}$, sandy loam soil and a welldistributed rainfall of 850-900 $\mathrm{mm}$ per annum. It matures in 3-9 months duration or longer depending on the variety. In India, sweet potato occupies an area over 111 thousand hectares with production of 1338 thousand tonnes. Sweet potato is cultivated throughout India but the main sweet potato growing states are Bihar, Orissa, Uttar Pradesh, Madhya Pradesh, Maharashtra and Karnataka. In Rajasthan it cultivates over an area of 790 hectares with production of 2240 tonnes and productivity $3040 \mathrm{~kg}$ per hectare (Anonymous, 2016). Sweet potato is the main source of starch and contains 10 per cent starch and 3-6 
percent sugar. Tubers are good source of vitamin $\mathrm{A}, \mathrm{B}, \mathrm{C}$ and minerals like phosphorus, iron and calcium. Yellow and orange flesh varieties of sugarbeet have more carotene content (Choudhary, 2014).

In India, the mixed farming system with livestock raising is an integral part of crop production. The farm yard manure is rich in organic matter content and used to supplement the nutrients for plants. The organic manure (FYM) not only provides nutrients to the plants but also improves the soil texture by binding of soil aggregates. Organic manure increases CEC, water holding capacity and phosphate availability of the soil besides improving the fertilizer use efficiency and microbial population in the soil as well as also reduces nitrogen loss by slow release of nitrogen in the soil.

In recent years, use of vermicompost has been advocated in vegetable crops. Vermicompost is a slow nutrient releasing organic manure which have most of the macro as well as micro nutrients in chelated form and fulfill the nutrient requirement of plants for longer period. Vermicompost helps in reducing $\mathrm{C}: \mathrm{N}$ ratio, increased humic acid content, cation exchange capacity and water soluble carbohydrates (Talashilkar et al., 1999).

It also contains biologically active substance such as plant growth regulators. Poultry manure is valuable manure and can serve as a suitable alternate to chemical fertilizers. Poultry manure application registered over 53 per cent increases of $\mathrm{N}$ level in the soil, from 0.09 per cent to 0.14 per cent and exchangeable cations also increased with the application of poultry manure (Boateng et al., 2006). In agriculture, the main reason for applying poultry manure is to add of organic amendment to the soil and to provide nutrients in sufficient quantity to the crops through organic source (Warren et al., 2006).
Bio-fertilizer liberates growth promoting substances and vitamins and helps in maintaining the soil fertility. They acts as antagonists and suppress the incidence of soil borne plant pathogens and thus, helps in the bio-control of diseases. Nitrogen fixing, phosphate mobilizing and cellulolytic microorganisms in bio-fertilizers enhance the availability of plant nutrients in the soil and thus, helps in sustainable agricultural production and farming systems. Azotobacters are free-living bacteria that fix atmospheric nitrogen in cereal crops without any symbiosis and they do not need a specific host plant. Azotobacters are abundant in well drained, neutral soil.

They can fix $15-20 \mathrm{~kg} / \mathrm{ha} \mathrm{N}$ per year. Azotobacter species can also produce antifungal compounds to fight against many plant pathogens. They also increase germination of seeds and vigour in young plants leading to improved crop stands (Siddiqui et al., 2014).

\section{Materials and Methods}

\section{Experimental details}

A field experiment was conducted to study effect of organic and inorganic sources of NPK and bio-fertilizer on enhancement of growth attributes and chlorophyll content of sweet potato (Ipomoea batatas Lam.) $c v$. IGSP-14 during Kharif season 2016 at Horticulture Farm, S.K.N. College of Agriculture, Jobner, Jaipur (Rajasthan). The experiment consists of 16 treatment combinations viz., organic and inorganic sources of NPK (Control, $100 \%$ RDF, $100 \%$ FYM, 50\% RDF + $50 \%$ FYM, $100 \%$ vermicompost, $50 \% \mathrm{RDF}+50 \%$ vermicompost, $100 \%$ poultry manure and 50 $\%$ RDF $+50 \%$ poultry manure denoted by symbols $\mathrm{I}_{0}, \mathrm{I}_{1}, \mathrm{I}_{2}, \mathrm{I}_{3}, \mathrm{I}_{4}, \mathrm{I}_{5}, \mathrm{I}_{6}$ and $\mathrm{I}_{7}$ ) and biofertilizer (Control and Azotobacter denoted by 
symbols $\mathrm{B}_{0}$ and $\mathrm{B}_{1}$ ) were tested in randomized block design with three replications.

The vine cuttings were cut for transplanting to the nursery beds when they have six to eight well developed leaves and a good root system. The vines were planted on $20^{\text {th }}$ August, 2016. The doses of organic and inorganic sources of N P K are FYM @ 20 t/ha, Poultry manure @ 5 t/ha, Vermicompost @ 7 t/ha and recommended dose of $\mathrm{N} \mathrm{P} \mathrm{K} \mathrm{is} \mathrm{100,} 60$ and $120 \mathrm{~kg}$ per ha respectively. The dose of azotobacter is $400 \mathrm{ppm}$.

\section{Climate and weather}

The climate of this region is typically semiarid, characterized by extremes of temperature during summer and winter season. The average annual rainfall ranges between 300$400 \mathrm{~mm}$, most of which is contributed by the South-West monsoon during July to August. The soil was loamy sand in texture, slightly alkaline in reaction, poor in organic carbon with low available nitrogen, phosphorus and medium in potassium.

\section{Application of treatments}

\section{NPK application}

As per the treatments nitrogen, phosphorus and potassium were applied through urea, single super phosphate and murate of potash, respectively in the experiment. The recommended dose of NPK was 100: 60: 120 $\mathrm{kg} \mathrm{ha}^{-1}$.

\section{FYM}

As per the treatment well rotten FYM was applied @ $20 \mathrm{t} \mathrm{ha}^{-1}$ and $10 \mathrm{t} \mathrm{ha}^{-1}$ and spreaded and incorporate uniformly in the beds. For the bed size of $2.40 \mathrm{~m} \times 2.25 \mathrm{~m}$, its quantity was calculated and applied after laying out the field before planting of vines.

\section{Poultry manure}

As per the treatment poultry manure was applied @ $6.6 \mathrm{t} \mathrm{ha}^{-1}$ and $3.3 \mathrm{t} \mathrm{ha}^{-1}$ and spreaded uniformly and incorporated in the beds. For the bed size of $2.40 \mathrm{~m} \times 2.25 \mathrm{~m}$, its quantity was calculated and applied after laying out the field before planting of vines.

\section{Vermicompost}

The vermicompost was applied @ $5 \mathrm{t} \mathrm{ha}^{-1}$ and $2.5 \mathrm{t} \mathrm{ha}^{-1}$ as per the treatments and spreaded uniformly and incorporated in the beds. For the bed size of $2.40 \mathrm{~m} \times 2.25 \mathrm{~m}$, its quantity was calculated and applied after laying out the field before planting of vines.

\section{Treatment evaluations/measurements}

Data on all the growth parameters were measured at different time in five randomly selected plants/vines of each treatment after sowing.

\section{Estimation of chlorophyll content in leaves (mg/g)}

The chlorophyll content of sweet potato leaves at 50 days after planting was estimated through the method advocated by Arnon (1949). The leaf sample of $100 \mathrm{mg}$ was grinded in $10 \mathrm{ml}$ of 80 percent acetone, centrifuged for 10 minutes at $2000 \mathrm{rpm}$ and prepared final volume to $10 \mathrm{ml}$. The resultant absorbance of clear supernatant was measured by spectronic 20 at $652 \mathrm{~nm}$ and presented in terms of $\mathrm{mg} / \mathrm{g}$ fresh weight of leaves.

A ${ }_{(652)}$ X 29 X Total volume (ml)

Total chlorophyll $(\mathrm{mg} / \mathrm{g})=$

$\alpha$ X 1000 X Weight of sample (g)

Where,

$\mathrm{A}=$ Absorbance specific wave lengths $\alpha$ is the path length $=1 \mathrm{~cm}$ 


\section{Statistical analysis}

To test the significance of variance in the data obtained from the various growth characters the technique of analysis of variance was adopted as suggested by Fisher (1950) for randomized block design. Significance of difference in the treatment effect was tested through ' $F$ ' test at 5 percent level of significance and $\mathrm{CD}$ (critical difference) was calculated, wherever the results found significant.

\section{Results and Discussion}

\section{Effect of organic and inorganic sources of NPK on growth attributes}

The data (Table 1 and Fig. 1) regarding the Length of vine $(\mathrm{cm})$ and number of branches per vine at 45 DAP revealed significant effect of organic and inorganic sources of NPK. The maximum vine length $(80.65 \mathrm{~cm})$ and number of branches per vine (5.99) recorded with 50\% $\mathrm{RDF}+50 \%$ vermicompost $\left(\mathrm{I}_{5}\right)$, while minimum vine length $(51.24 \mathrm{~cm})$ and number of branches per vine (3.60) in control. However, treatment $I_{5}$ was statistically at par with $50 \% \mathrm{RDF}+50 \%$ poultry manure $\left(\mathrm{I}_{7}\right)$. The increase in vine length and number of branches per vine under 50\% RDF $+50 \%$ vermicompost was registered 57.40, 13.26, $28.96,8.14,18.10,23.87$ and $66.39,27.45$, $47.90,22.24,39.30$ and 1.53 per cent more over $\mathrm{I}_{0}, \mathrm{I}_{1}, \mathrm{I}_{2}, \mathrm{I}_{3}, \mathrm{I}_{4}$ and $\mathrm{I}_{6}$, respectively. In the present investigation, significant increase was observed in vine length, number of branches and number of leaves per plant with different sources of organic and chemical fertilizers. Similarly, findings are also reported by Cortez jaun et al., (2010). They explained that organic manures not only slowly releases the nutrients from itself but also prevents losses of chemical fertilizers through denitrification, volatilization and leaching by binding the nutrients and releasing for crop use with the passage of time. The findings of the present study clearly indicated that vermicompost played a significant role in enhancing the growth of sweet potato. The beneficial effect of vermicompost on plant growth might be attributed to the fact that the earthworms mineralized the macro and micronutrients during vermicomposting and made available to crop plants for longer period. In addition, it also improved soil structure, aeration and water holding capacity of the soil. These results are in close conformity with the findings of Vanmathi and Selvakumari (2012).

The application of poultry manure also enhanced the vegetative growth of sweet potato, which might be due to higher nutrient content, rapid mineralization, optimum $\mathrm{C} / \mathrm{N}$ ratio and more availability of nitrogen, leading to better growth and yield. Addition of poultry manure also helps in reduction in soil $\mathrm{pH}$ due to liberation of $\mathrm{CO}_{2}$ and organic acids during decomposition and the decomposition product may give rise to naturally complexing agents and also increases soil biomass which solublizes the native soil nutrients in available form for the plants. These results are in agreement with findings of Anjali et al., (2006). Poultry manure might have provided nutrients to the plant in readily available form for easy absorption by the plant roots, hence there was a boost in the morphological growth of the plant (Onwu et al., 2014).

It is amply clear from data presented in Table 1 and depicted in Figure 2 that organic and inorganic sources of NPK significantly influenced the leaf area $\left(\mathrm{cm}^{2}\right)$ at 45 days after planting and leaf area index of sweet potato. The maximum leaf area $\left(14850.20 \mathrm{~cm}^{2}\right)$ and leaf area index (11.00) were recorded with $50 \%$ RDF $+50 \%$ vermicompost, while minimum leaf area $\left(7025.45 \mathrm{~cm}^{2}\right)$ and leaf area index (5.20) were recorded under control. Treatment $I_{5}$ found statistically at par with $50 \%$ RDF $+50 \%$ poultry manure. The 
increase in leaf area and leaf area index under $50 \%$ RDF $+50 \%$ vermicompost was registered $111.38,48.35,62.38,31.53,51.08$, $55.89,7.73$ and $111.38,48.35,62.38,31.53$, $51.08,55.89,7.73$ per cent more over $\mathrm{I}_{0}, \mathrm{I}_{1}, \mathrm{I}_{2}$, $\mathrm{I}_{3}, \mathrm{I}_{4}$ and $\mathrm{I}_{6}$, respectively. The increase in plant growth attributes with the application of poultry manure and vermicompost might be due to the fact that organic manures not only provided nutrients to the plant but also improved the physical condition of soil in respect of granulation, friability, porosity and developed a balanced nutritional environmental in both soil rhizosphere and plant system. The increase in plant growth characters with the application of vermicompost, poultry manure and Azotobacter in combination with $50 \%$ or $100 \%$ RDF might be due to better availability of plant nutrients and maintenance of balanced $\mathrm{C}: \mathrm{N}$ ratio throughout the growing period of the crop (Marimuthu et al., 2002 and Surrender Rao and Sitaramaya, 2000).

\section{Effect of organic and inorganic sources of NPK on chlorophyll content}

It is explicit from the data (Table 1 and Fig. 3) that the chlorophyll content in leaves at 50 DAP was significantly affected by organic and inorganic sources of NPK. The maximum chlorophyll content $(1.23 \mathrm{mg} / \mathrm{g})$ recorded with $50 \%$ RDF $+50 \%$ vermicompost $\left(\mathrm{I}_{5}\right)$, while minimum Chlorophyll $(0.88 \mathrm{mg} / \mathrm{g})$ content in leaves recorded under control. Treatment $\left(\mathrm{I}_{5}\right)$ was found statistically at par with 50\% RDF + $50 \%$ poultry manure. The increase in chlorophyll content under 50\% RDF $+50 \%$ vermicompost was registered 39.77, 7.89, $10.81,6.96,8.85$ and 9.82 per cent more over $\mathrm{I}_{0}, \mathrm{I}_{1}, \mathrm{I}_{2}, \mathrm{I}_{3}, \mathrm{I}_{4}$ and $\mathrm{I}_{6}$, respectively. The integration of organic manures in combination with inorganic fertilizers was found significant in improving the overall plant growth, yield and soil macro nutrient status than the sole application of either of these nutrients. The combined use of organic and inorganic nutrients might improve in solubilization of plant nutrients that lead to increased uptake of NPK. Combined application of organic and inorganic sources of NPK reduces the nutrient losses, improve fertilizer use efficiency and thereby increased soil nutrient availability for the plants (Prativa and Bhattarai, 2011).

The better efficiency of organic and inorganic sources of NPK might be due to the fact that the organic manures would have provided the micronutrients in an optimum range to the plant. Application of organic manures would have helped in enhancing the metabolic activities in the plant system through the supply of such important micronutrients in the early growth phase which in turn must have encouraged the overall growth of the vines per plant. This is in close conformity with the findings of Azad (2000), who have also reported highest plant growth due to the combined application of organic manures and chemical fertilizers in tomato.

\section{Effect of biofertilizers on growth attributes}

Data (Table 1 and Fig. 1) further indicated that the application of bio-fertilizer significantly influenced the vine length at 45 DAP and number of branches per vine. The maximum vine length $(82.87 \mathrm{~cm})$ and number of branches per vine (5.01) recorded in treatment $\mathrm{B}_{1} \quad$ (Azotobacter), which was found significantly superior over control. The increase in vine length and number of branches per vine under the treatment $B_{1}$ was found to be 51.11 and 14.13 per cent more as compared to control. These findings clearly indicate that Azotobacter played a significant role in enhancing the growth attributes of sweet potato vines. Azotobacter liberates growth promoting substances and vitamins and helps to maintain soil fertility. 
Fig.1 Effect of organic and inorganic sources of NPK and bio-fertilizer on length of vine $(\mathrm{cm})$ and number of branches per vine at $45 \mathrm{DAP}$ of sweet potato
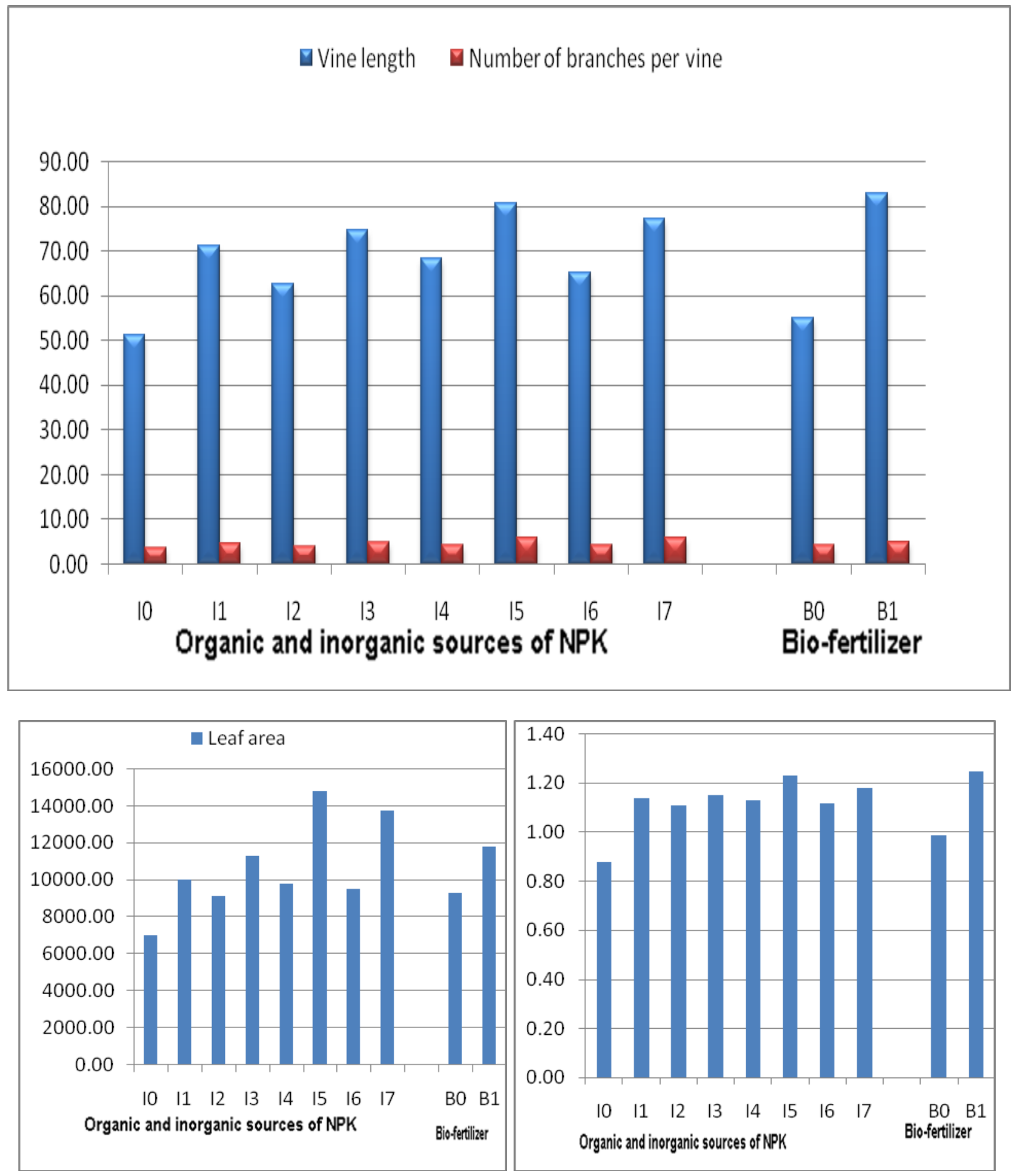

Fig.2 Effect of organic and inorganic sources of NPK and bio-fertilizer on leaf area $\left(\mathrm{cm}^{2}\right)$ at 45 DAP of sweet potato

Fig.3 Effect of organic and inorganic sources of NPK and bio-fertilizer on chlorophyll content $(\mathrm{mg} / \mathrm{g})$ at 50 DAP of sweet potato 
Table.1 Effect of organic and inorganic sources of NPK and biofertilizer on enhancement of growth attributes and Chlorophyll content of sweet potato

\begin{tabular}{|c|c|c|c|c|c|}
\hline Treatment & $\begin{array}{l}\text { Vine length } \\
\text { (cm) }\end{array}$ & $\begin{array}{c}\text { Number of branches } \\
\text { per vine }\end{array}$ & $\begin{array}{l}\text { Leaf area } \\
\qquad\left(\mathrm{cm}^{2}\right)\end{array}$ & $\begin{array}{c}\text { Leaf area } \\
\text { index }\end{array}$ & $\begin{array}{c}\text { Chlorophyll } \\
\text { content }(\mathrm{mg} / \mathrm{g})\end{array}$ \\
\hline \multicolumn{6}{|c|}{ Organic and inorganic sources of NPK } \\
\hline $\mathrm{I}_{0}$ - Control & 51.24 & 3.60 & 7025.45 & 5.20 & 0.88 \\
\hline $\mathrm{I}_{1}-100 \% \mathrm{RDF}$ & 71.21 & 4.70 & 10010.25 & 7.42 & 1.14 \\
\hline $\mathrm{I}_{2}-100 \% \mathrm{FYM}$ & 62.54 & 4.05 & 9145.25 & 6.77 & 1.11 \\
\hline $\mathrm{I}_{3}-50 \% \mathrm{RDF}+50 \% \mathrm{FYM}$ & 74.58 & 4.90 & 11290.51 & 8.36 & 1.15 \\
\hline $\mathrm{I}_{4}-100 \%$ Vermicompost & 68.29 & 4.30 & 9829.52 & 7.28 & 1.13 \\
\hline $\mathrm{I}_{5}-50 \% \mathrm{RDF}+50 \% \mathrm{VC}$ & 80.65 & 5.99 & 14850.20 & 11.00 & 1.23 \\
\hline $\mathrm{I}_{6}-100 \%$ Poultry Manure & 65.11 & 4.15 & 9525.92 & 7.06 & 1.12 \\
\hline $\mathrm{I}_{7}-50 \% \mathrm{RDF}+50 \% \mathrm{PM}$ & 77.25 & 5.90 & 13785.28 & 9.47 & 1.18 \\
\hline S.Em. \pm & 1.24 & $\mathbf{0 . 0 3}$ & 405.73 & 0.54 & 0.03 \\
\hline $\mathrm{CD}(\mathrm{P}=\mathbf{0 . 0 5})$ & 3.58 & 0.10 & 1171.84 & 1.57 & 0.07 \\
\hline \multicolumn{6}{|l|}{ Biofertilizer } \\
\hline $\mathrm{B}_{0}-$ Control & 54.84 & 4.39 & 9307.23 & 6.89 & 0.99 \\
\hline $\mathrm{B}_{1}-$ Azotobacter & 82.87 & 5.01 & 11808.52 & 8.75 & 1.25 \\
\hline S.Em. \pm & 0.76 & 0.02 & 248.46 & 0.33 & 0.02 \\
\hline $\mathrm{CD}(\mathrm{P}=\mathbf{0 . 0 5})$ & 2.19 & 0.06 & 717.60 & 0.96 & 0.05 \\
\hline
\end{tabular}


Azotobacters are free-living bacteria that fix atmospheric nitrogen in vegetable crops without any symbiosis and they do not need a specific host plant. (Jnawali et al., 2015)

A critical review of data in similar Table revealed that application of bio-fertilizer significantly influenced the leaf area at 45 DAP and leaf area index. The maximum leaf area $\left(11808.52 \mathrm{~cm}^{2}\right)$ and leaf area index (8.75) were recorded with treatment $B_{1}$ (Azotobacter), which was found significantly superior over control $\left(9307.23 \mathrm{~cm}^{2}\right.$ and 6.89$)$. The increase in leaf area and leaf area index under the treatment $\mathrm{B}_{1}$ was found to be 26.87 and 26.87 per cent higher as compared to control. Azotobacter has beneficial effect on crop growth and yield through, biosynthesis of biologically active substances, stimulation of rhizospheric microbes and producing phyopathogenic inhibitors, modification of nutrient uptake and ultimately boosting biological nitrogen fixation in the plants. The presence of Azotobacter sp. in soils has beneficial effects on plants, but the abundance of these bacteria is related to many factors such as soil physico-chemical (e.g. organic matter, $\mathrm{pH}$, temperature, soil moisture) and microbiological properties. Its abundance varies with the depth of the soil profile. Azotobacter is much more abundant in the rhizosphere of plants that is surrounding the soil around the plant roots and this abundance also depends on the crop species (Jnawali et al., 2015).

\section{Effect of biofertilizers on chlorophyll content}

A critical analysis of data (Table 1 and Fig. 3) revealed that application of bio-fertilizer significantly influenced the chlorophyll content of leaves of sweet potato at 50 DAP. The maximum chlorophyll content (1.25 $\mathrm{mg} / \mathrm{g}$ ) recorded in treatment $\mathrm{B}_{1}$ (Azotobacter), which was found significantly superior over control (0.99). The increase in chlorophyll content under the treatment $B_{1}$ was found to be 26.44 per cent higher as compared to control. The important characteristic of Azotobacter association with crop improvement is secretion of ammonia in the rhizosphere in presence of root exudates, which helps in modification of nutrient uptake by the plants. The ability of Azotobacter to produce plant growth regulatory substances along with $\mathrm{N}_{2}$ fixation stimulates plant growth, productivity and quality. The changes that occur in the plant roots help in better transport of minerals and water in the plant system. All these factors produce positive effects on crop yield especially for vegetables and cereals (Ramakrishnan and Selvakumar, 2012).

\section{References}

Anjali, D., Warade, S.D., Anarse, S.A., Rashmi Bhoge and Amolic, V. L. 2006. Effect of organic manures on growth, yield and keeping quality of okra (Abelmoschus esculentus L.) cv. Phule Kirti. Annual Review of Plant Physiology, 20(1): 65-68

Anonymous, 2016. Indian Horticulture Database-2016. National Horticultural Board, Gurgaon.

Arnon, D.I. 1949. Copper enzymes in isolated chloroplast polyphenol oxidase in Beta vulgaris. Physiology, 24: 1-5.

Azad, A.K. 2000. Effects of plant spacing, source of nutrients and mulching on growth and yield of cabbage. M.Sc. Thesis. Department of Horticulture, Bangladesh Agriculture University, Mymensingh, pp.15-40.

Boateng, S., Zickermann, A.J. and Kornaharens, M. 2006. Effect of poultry manure on growth and yield of maize. West Africa Journal of Applied Ecology, 9:1-11.

Choudhary, B.R. 2014. Vegetables. Kalyani 
publishers, $264-269$.

Cortez jaun, W., Filho Arthur, B. and Countinho edson, L. 2010. Cattle manure and $\mathrm{N}$-urea in radish crop (Raphanus sativus). Ciencia $e$ Investigacion Agraria, 37 (1): 45-53.

Fisher, R.A. 1950. Statistical Methods for Research Workers. Oliver and Boyd Edinburgh, London.

Jnawali, A. D., Ojha, R. B. and Marahatta, S. 2015. Role of Azotobacter in Soil Fertility and Sustainability. Advances in Plants \& Agriculture Research, 2(6): 69.

Marimuthu, R., Babu, S., and Vairavan 2002. Utility of different sources of vermicompost and in nutrient status on the growth and yield of nutrient of groundnut cv. VRI 2. Legume Research, 25: 266-269.

Onwu, A. C., Abubakar, J. R. and Unah, P. O. 2014. Effect of poultry manure on growth, yield of okra and soil properties in Makurdi, North Central Nigeria. International Journal of Agricultural and Food Science, ISSN 2249-8516.

Prativa, K.C. and Bhattarai, B.P. 2011. Effect of Integrated nutrient management on the growth, yield and soil nutrient status in tomato. Nepal Journal of Science and Technology, 12: 23 - 28.

Ramakrishnan, K. and Selvakumar, G. 2012. Effect of biofertilizers on enhancement of growth and yield on Tomato
[Lycopersicum esculentum (Mill.)]. International Journal of Research in Botany, 2(4): 20-23.

Siddiqui, A.K., Shivle, R. and Mangodia, N. 2014. Possible role of Biofertilizer in organic agriculture. International Journal of Innovative Research and Studies, 3(9): 2319-9725.

Surrender Rao, S. and Sitaramaya, M. 2000. Performance of alternate organic nitrogen sources in an inceptisol under rice. In proceedings of International Conference Managing Natural Resources for Sustainable Agricultural Production in the $21^{\text {st }}$ Century, New Delhi, 3, 1464-1465.

Talashilkar, S.C., Bhangarath, P.P. and Mehta 1999. Changes in chemical properties during composting of organic residues as influenced by earthworm activity. Journal of the Indian Society Soil Science, 47 (1): 50-53.

Vanmathi, J.S. and Selvakumari, M.N. 2012. The influence of vermicompost on the growth and yield of Hibiscus esculentus. Elixir Applied Botany, 44: 7416-7419.

Warren, J.G., Phillips, S.B., Mullins, G.L., Keahey, D. and Penn C.J. 2006. Environmental and production consequences of using alum amended poultry litter as a nutrient source for corn. Journal of Environmental Quality, 35: 172-182.

\section{How to cite this article:}

Jai Singh, M.K. Sharma, S.P. Singh, Rukshana Bano and Mahawar, A.K. 2018. Effect of Organic and Inorganic Sources of NPK and Bio-fertilizer on Enhancement of Growth Attributes and Chlorophyll Content of Sweet Potato. Int.J.Curr.Microbiol.App.Sci. 7(09): 3659-3667. doi: https://doi.org/10.20546/ijcmas.2018.709.455 